\title{
Front Matter: Volume 9508
}

, "Front Matter: Volume 9508," Proc. SPIE 9508, Holography: Advances and Modern Trends IV, 950801 (20 May 2015); doi: 10.1117/12.2197888

SPIE. Event: SPIE Optics + Optoelectronics, 2015, Prague, Czech Republic 


\title{
PROCEEDINGS OF SPIE
}

\section{Holography: Advances and Modern Trends IV}

\author{
Miroslav Hrabovský \\ John T. Sheridan \\ Antonio Fimia \\ Editors
}

15-16 April 2015

Prague, Czech Republic

Sponsored by

SPIE

Cooperating Organisations

HiPER Project (United Kingdom)

ELI Beamlines (Czech Republic)

Laserlab Europe

Published by

SPIE 
The papers included in this volume were part of the technical conference cited on the cover and title page. Papers were selected and subject to review by the editors and conference program committee. Some conference presentations may not be available for publication. The papers published in these proceedings reflect the work and thoughts of the authors and are published herein as submitted. The publisher is not responsible for the validity of the information or for any outcomes resulting from reliance thereon.

Please use the following format to cite material from this book:

Author(s), "Title of Paper," in Holography: Advances and Modern Trends IV, edited by

Miroslav Hrabovský, John T. Sheridan, Antonio Fimia, Proceedings of SPIE Vol. 9508 (SPIE, Bellingham, WA, 2015) Article CID Number.

ISSN: 0277-786X

ISBN: 9781628416299

\section{Published by}

\section{SPIE}

P.O. Box 10, Bellingham, Washington 98227-0010 USA

Telephone +1 3606763290 (Pacific Time) · Fax +1 3606471445

SPIE.org

Copyright @ 2015, Society of Photo-Optical Instrumentation Engineers.

Copying of material in this book for internal or personal use, or for the internal or personal use of specific clients, beyond the fair use provisions granted by the U.S. Copyright Law is authorized by SPIE subject to payment of copying fees. The Transactional Reporting Service base fee for this volume is $\$ 18.00$ per article (or portion thereof), which should be paid directly to the Copyright Clearance Center (CCC), 222 Rosewood Drive, Danvers, MA 01923. Payment may also be made electronically through CCC Online at copyright.com. Other copying for republication, resale, advertising or promotion, or any form of systematic or multiple reproduction of any material in this book is prohibited except with permission in writing from the publisher. The CCC fee code is 0277-786X/15/\$18.00.

Printed in the United States of America.

Publication of record for individual papers is online in the SPIE Digital Library.

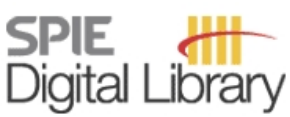

SPIEDigitalLibrary.org

Paper Numbering: Proceedings of SPIE follow an e-First publication model, with papers published first online and then in print. Papers are published as they are submitted and meet publication criteria. A unique citation identifier (CID) number is assigned to each article at the time of the first publication. Utilization of CIDs allows articles to be fully citable as soon as they are published online, and connects the same identifier to all online, print, and electronic versions of the publication. SPIE uses a six-digit CID article numbering system in which:

- The first four digits correspond to the SPIE volume number.

- The last two digits indicate publication order within the volume using a Base 36 numbering

system employing both numerals and letters. These two-number sets start with $00,01,02,03$,

04, 05, 06, 07, 08, 09, 0A, OB ... 0Z, followed by 10-1Z, 20-2Z, etc.

The CID Number appears on each page of the manuscript. The complete citation is used on the first page, and an abbreviated version on subsequent pages. 


\title{
Contents
}

\author{
vii Authors \\ ix Conference Committee
}

\section{SESSION 1 DIGITAL HOLOGRAPHY}

950802 Sparse approximations of phase and amplitude for wave field reconstruction from noisy data (Invited Paper) [9508-1]

950803 Real-time characterization of the neuronal response to osmotic shock by digital holographic microscopy [9508-2]

950804 Fluorescence digital holographic adaptive optics microscopy [9508-4]

SESSION 2 HOLOGRAPHIC SECURITY

950805 Plasmonic spectral filters based on diffraction gratings [9508-6]

950806 Security hologram foil labels with a design facilitating authenticity testing: effects of mechanical bending of substrates with the glued on holograms [9508-7]

\section{SESSION 3 HOLOGRAPHIC MATERIALS AND DATA STORAGE}

950807 Volume holographic gratings: fabrication and characterization (Invited Paper) [9508-8]

950808 Theoretical analysis of diffraction characteristics for peristrophic multiplexing with spherical reference wave [9508-9]

950809 Humidity and temperature response of photopolymer-based holographic gratings [9508-10]

9508 OA Read-out optical schemes for holographic memory system based on multiplexed computer generated ID Fourier holograms [9508-11]

\section{SESSION 4 HOLOGRAPHIC MATERIALS AND MODELLING}

$9508 \mathrm{OB}$ Three-dimensional numerical model of holographic grating formation in photopolymer materials (Invited Paper) [9508-13]

9508 OC Photorefractive amplification of dynamic light signals using photoconductive ferroelectric liquid crystals [9508-14]

9508 OD Formation of dissipative structures at hologram recording in $\mathrm{CaF}_{2}$ crystals with color centers [9508-15] 
9508 OE Advances in photo-thermo-refractive glass composition modifications [9508-16]

SESSION 5 HOLOGRAPHIC IMAGING, FABRICATION, AND MATERIALS I

9508 OF Self-trapping of optical beams in a self-written channel in a solid bulk photopolymer material (Invited Paper) [9508-17]

9508 OG Second harmonics HOE recording in Bayfol HX [9508-18]

$9508 \mathrm{OH} \quad$ Lab-level and low-cost fabrication technique for polymer based micro-optical elements and holographic structures [9508-19]

9508 Ol Comparison of a new photosensitizer with Erythrosin B for use in a photopolymer [9508-20]

9508 0J Diffractive optical elements with an increased angular and wavelength range of operation for application in solar collectors [9508-23]

SESSION 6 HOLOGRAPHIC IMAGING, FABRICATION, AND MATERIALS II

9508 OK Holographic wavefront sensors: state of the art and prospects (Invited Paper) [9508-22]

$9508 \mathrm{OL}$ Incoherent holography with the use of Shack-Hartmann wavefront sensor [9508-21]

$95080 \mathrm{M}$ Challenges in holographic measurement of aspheric and freeform optical components shape [9508-24]

$95080 \mathrm{~N}$ Advanced time average holographic method for measurement in extensive vibration amplitude range with quantitative single-pixel analysis (Best Student Paper Award) [9508-25]

950800 All-optically controlled light valve assembled by photorefractive crystal and PDLC hybrid structure [9508-26]

POSTER SESSION

$9508 \mathrm{OP}$ Comparison of digital holographic interferometry and constant temperature anemometry for measurement of temperature field in fluid [9508-3]

$95080 Q \quad$ Image fusion using bi-directional similarity [9508-12]

9508 OR Design and experiments of combined diffractive optical element for virtual displays and indicators [9508-27]

9508 OU Modeling of effect of LC SLM phase fluctuations on kinoforms optical reconstruction quality [9508-30]

9508 OV Retractions of the gingival margins evaluated by holographic methods [9508-31] 
9508 OW Photorefractive phase-conjugation digital holographic microscopy [9508-32]

9508 0X Estimation of objects transverse parameters in off-axis and in-line Fresnel digital holography [9508-33]

9508 OY Study of transparent particles in the volume of optical medium using digital holography and singular-optics approach [9508-34]

$95080 Z$ Application of fractal masks with spiral phase distribution for the determination phase discontinuities in transparent objects [9508-35]

950810 Spectral analysis in overmodulated holographic reflection gratings recorded with BB640 ultrafine grain emulsion [9508-36]

950811 Amplitude-phase type fractal screens and their application in phase-retrieval method [9508-37]

950812 Synthesis of Fourier holograms for recognition of radiation sources with continuous spectra by dispersive correlators [9508-38]

950813 Direct real-time measurement of shrinkage in photopolymer materials during recording of reflection gratings [9508-39] 
Proc. of SPIE Vol. $9508950801-6$

Downloaded From: https://www.spiedigitallibrary.org/conference-proceedings-of-spie on 26 Apr 2023 Terms of Use: https://www.spiedigitallibrary.org/terms-of-use 


\title{
Authors
}

Numbers in the index correspond to the last two digits of the six-digit citation identifier (CID) article numbering system used in Proceedings of SPIE. The first four digits reflect the volume number. Base 36 numbering is employed for the last two digits and indicates the order of articles within the volume. Numbers start with 00, 01, 02, 03, 04, 05, 06, 07, 08, 09, 0A, OB...0Z, followed by 10-1Z, 20-2Z, etc.

\author{
Akbari, H., OJ \\ Angervaks, Aleksandr E., OD \\ Aubrecht, Ivo, 06 \\ Bai, Chunshan, $0 Q$ \\ Betin, Alexandr Y., OA \\ Bianco, G., 07 \\ Bobrinev, Vladimir I., OA \\ Borbone, F., 07 \\ Boroz, Kristian, $\mathrm{OH}$ \\ Bruder, Friedrich-Karl, OG \\ Chan, Huang-Tian, OW \\ Chang, Chi-Ching, OW \\ Chen, Ming Syuan, 00 \\ Cheremkhin, Pavel A., OU, OX \\ Chew, Yang-Kun, OW \\ Cody, Dervil, 09 \\ Coppola, G., 07 \\ Dančová, Petra, OP \\ de Sabata, Aldo, OV \\ Dlask, Martin, OM \\ Doleček, Roman, OM, ON, OP \\ Donchenko, Sergey S., OA \\ Dudea, Diana, OV \\ Dughir, Ciprian, OV \\ Duma, Virgil-Florin, OV \\ Egiazarian, Karen, 02 \\ Evtikhiev, Nikolay N., OU, OX \\ Fäcke, Thomas, OG \\ Fedorov, Pavel P., OD \\ Fernández, Eduardo, 03 \\ Ferrara, M. A., 07 \\ Ferraro, P., 07 \\ Fimia, Antonio, 03, 10 \\ Fouassier, Jean Pierre, 이 \\ Garcia, Isabel, 03 \\ Gödeke, Dina, $\mathrm{OH}$ \\ Gomariz, Maria, 03 \\ Gorelaya, A. V., OL \\ Grilli, S., 07 \\ Hagen, Rainer, $0 G$ \\ Hönel, Dennis, OG \\ Hsu, Ken Yuh, 00 \\ Ignatiev, A. I., OE \\ Ivanov, S. A., OE \\ Katkovnik, Vladimir, 02 \\ Kelb, Christian, $\mathrm{OH}$ \\ Kopecký, Václav, OP \\ Krasnov, Vitaly V., OU, OX \\ Kuzin, A. A., 05
}

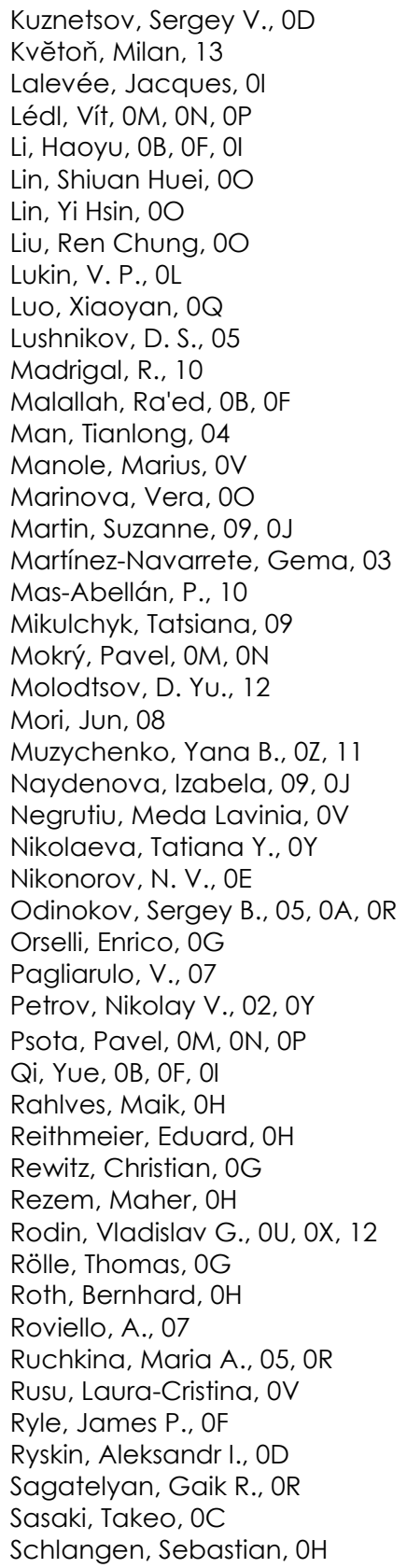


Sevryugin, A. A., OL

Shcheulin, Aleksandr S., OD

Sheridan, John T., OB, OF, Ol

Shevkunov, Igor A., 02

Shiu, Min-Tzung, OW

Shubenkova, E. V., OL

Sinescu, Cosmin, OV

Smirnov, A. V., 05

Solomashenko, Artem B., OR

Solovev, Maksim A., OK

Soto-Sánchez, Cristina, 03

Starikov, Sergey N., OU, OX, 12

Stratul, Stefan, OV

Striano, V., 07

Václavík, Jan, ON

Venediktov, Vladimir Yu., OK, OL

Veniaminov, Andrey $V .$, OD

Vít, Tomáš, OP

Vojtíšek, Petr, OM, 0N, 13

Walshe, James, 09

Walze, Günther, OG

Wan, Yuhong, 04

Wang, Dayong, 04

Wewer, Brita, OG

Yamamoto, Manabu, 08

Yoshida, Shuhei, 08

Zablotskiy, A. V., 05

Zherdev, Alexander Yu., 05, OR

Zinchik, Alexander A., OZ, 11

Zlokazov, Evgenie Y., OA 


\title{
Conference Committee
}

\author{
Symposium Chairs
}

Jiri Homola, Institute of Photonics and Electronics of the ASCR, v.v.i. (Czech Republic)

Chris Edwards, Central Laser Facility, Science and Technology

Facilities Council (United Kingdom)

Mike Dunne, SLAC National Accelerator Laboratory (United States)

and Linac Coherent Light Source (United States)

Ivo Rendina, Istituto per la Microelettronica e Microsistemi, CNR (Italy)

Honorary Symposium Chair

Miroslav Miller, Institute of Photonics and Electronics of the ASCR,

v.v.i. (Czech Republic)

Conference Chairs

Miroslav Hrabovský, Palacký University Olomouc (Czech Republic)

John T. Sheridan, University College Dublin (Ireland)

Antonio Fimia, Universidad Miguel Hernández de Elche (Spain)

Conference Programme Committee

Radim Chmelík, Brno University of Technology (Czech Republic)

Milos Kopecky, Institute of Physics of the ASCR, v.v.i. (Czech Republic)

Libor Kotacka, Optaglio s.r.o. (Czech Republic)

Miroslav Miler, Academy of Sciences of the Czech Republic

(Czech Republic)

Dagmar Senderáková, Comenius University in Bratislava (Slovakia)

Mitsuo Takeda, Utsunomiya University (Japan)

Vladimir Y. Venediktov, Saint Petersburg Electrotechnical University

"LETI" (Russian Federation)

Przemyslaw W. Wachulak, Military University of Technology (Poland)

Günther K. G. Wernicke, Humboldt-Universität zu Berlin (Germany)

Session Chairs

1 Digital Holography

Miroslav Hrabovský, Palacký University Olomouc (Czech Republic)

2 Holographic Security

John T. Sheridan, University College Dublin (Ireland) 
3 Holographic Materials and Data Storage

Antonio Fimia, Universidad Miguel Hernández de Elche (Spain)

4 Holographic Materials and Modelling

Miroslav Hrabovský, Palacký University Olomouc (Czech Republic)

5 Holographic Imaging, Fabrication, and Materials I

John T. Sheridan, University College Dublin (Ireland)

6 Holographic Imaging, Fabrication, and Materials II

Antonio Fimia, Universidad Miguel Hernández de Elche (Spain)

John T. Sheridan, University College Dublin (Ireland)

Miroslav Hrabovský, Palacký University Olomouc (Czech Republic) 